DOI dx.doi.org/10.24866/7444-4707-6/114-128

Б.Ф. Пиеничников, Е.А. Вихрова

\title{
СПЕЦИФИКА ФОРМИРОВАНИЯ БУРОЗЁМОВ НА ОСТРОВАХ ЗАЛИВА ПЕТРА ВЕЛИКОГО (ЮГ ДАЛЬНЕГО ВОСТОКА)
}

Современные представления о специфике островного почвообразования весьма неоднозначны и даже противоречивы. По мнению одних исследователей, нет оснований говорить о том, что островное почвообразование чем-то отличается от неостровного как процесс, и (это не означает невозможности появления локальных специфических черт почвообразования на некоторых островках в связи с их геологическим, климатическим или биотическим своеобразием) [1]. Другие исследователи находят основания для того, чтобы говорить о специфике островного почвообразования. Так, есть мнение, что генезис и география почв в прибрежной части японского моря и на островах во многом определяются современным геохимическим воздействием моря на процессы почвообразования. Исходя из вышесказанного, в пределах прибрежной части Японского моря и островах можно выделить «прибрежно-островную зону» с характерным для неё морским гидротермически-импульверизационным режимом [2]. В заливе Петра Великого находится множество островов, отличных друг от друга удаленностью от материка, степени антропогенной трансформации растительного покрова. Отдельные острова, такие как о. Русский, о. Попова, о. Путятина, о. Аскольд, имеют довольно крупные размеры. Также следует отметить и характер растительности. Так растительность вышеперечисленных островов в общих чертах близка к растительности на сопредельных частях материка.

Большинство островов имеют небольшие площади и в среднем составляют менее одного квадратного километра.

Природные процессы, происходящие на островах, отличаются от материковых процессов высокой степенью динамичности и напряженности, что обусловлено спецификой морского климата, площадью, степенью изоляции и временем отделения островов от материка [3]. Все эти условия определили процесс отбора видов растений на островах. 
Район исследования находится в муссонной области умеренного пояса, с сухой зимой и влажным летом. Согласно геоботаническому районированию эта территория относится к Дальневосточной хвойно-широколиственной области Маньчжурской провинции кедрово-широколиственных и дубовых лесов Хасанского округа [4]. Почвенный покров представлен зональными для буроземно-лесной области юга Дальнего Востока почвами буроземами типичными и буроземами темными [5].

Бухта Табунная и прилегающие к ней острова расположены в Хасанском районе Приморского края (рис. 1). Острова различаются по своим размерам и удаленности от материкового побережья.

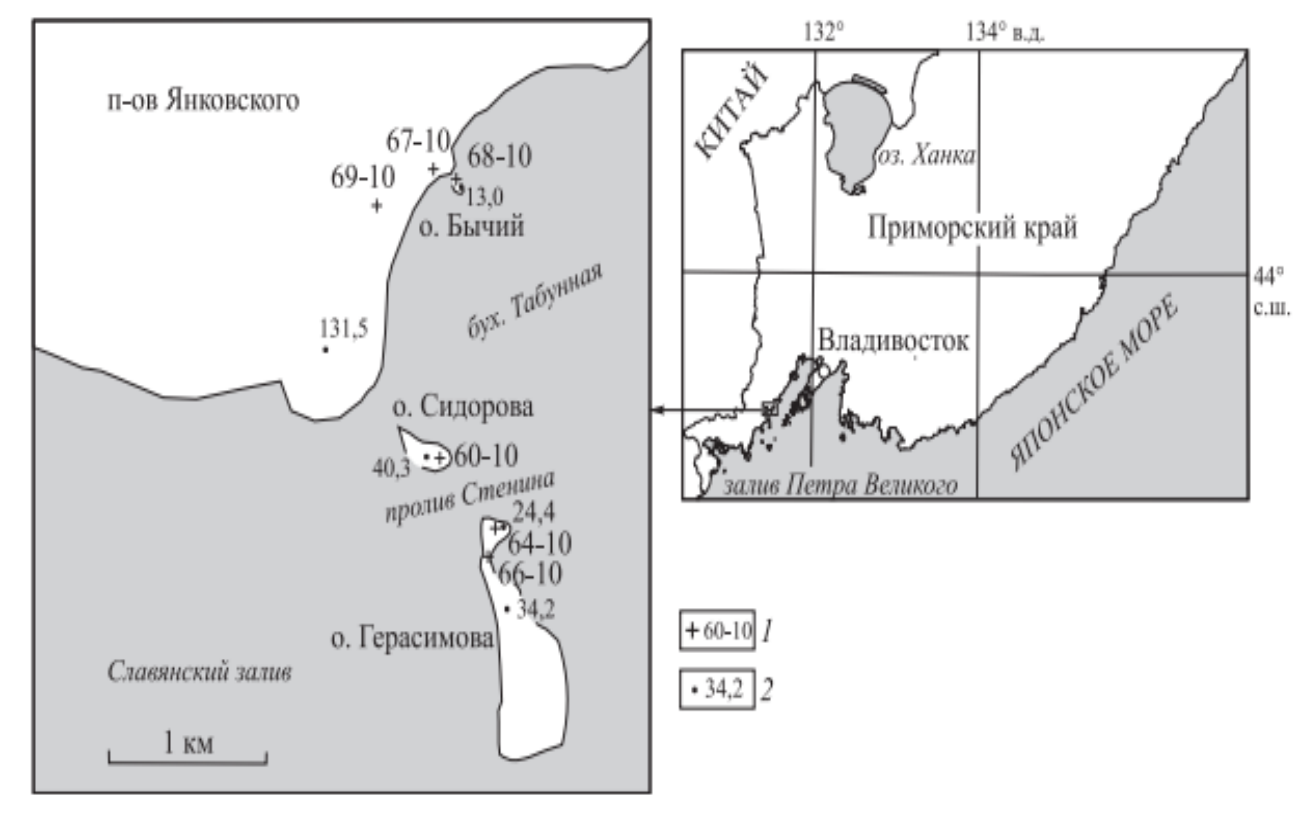

Puc. 1. Район исследования.

1 - почвенные разрезы; 2 - абс. высота над уровнем моря, м.

Площадь более удаленных островов Герасимова и Сидорова составляет 0,35 и 0,04 км2 соответственно, а почти примыкающего к берегу о. Бычий - 0,008 км2. Рельеф о. Герасимова низкогорный с максимальной высотой 34,2 м над уровнем моря, здесь преобладают изрезанные скалистые, обрывистые берега, присутствуют небольшие участки галечных пляжей. Острова Сидорова и Бычий представляют собой скальные массивы с обрывистыми берегами и выположенными вершинами. Максимальная высота над уровнем моря о. Сидорова - 40,3 м, о. Бычий - 13 м.

Район исследования находится в муссонной области умеренного пояса, с сухой зимой и влажным летом. Согласно геоботаническому райони- 
рованию эта территория относится к Дальневосточной хвойно-широколиственной области Маньчжурской провинции кедрово-широколиственных и дубовых лесов Хасанского округа. Почвенный покров представлен зональными для буроземно-лесной области юга Дальнего Востока почвами - буроземами типичными и буроземами темными.

Почвенные исследования выполнялись сравнительно-географическим методом [6], в различных типах ландшафтов было заложено 10 почвенных разрезов и отобраны образцы для физико-химических анализов. Для реконструкции динамики растительности и палеоэкологических условий из генетических горизонтов почвенных профилей отобраны пробы на споровопыльцевой анализ. Химикотехнологическая обработка образцов для спорово-пыльцевого анализа и статистический подсчет проводились по стандартным методикам [7]. Изучение спор и пыльцы осуществлялось с помощью светового биологического микроскопа Primo Star при увеличении 400.

Климат южного Приморья муссонный. Его характерными особенностями являются: устойчивые северные ветры зимой и южные и юговосточные летом, низкая годовая температура воздуха, неравномерное распределение осадков, периодические глубокие циклоны.

Фациальные черты климата [16] проявляются в более низких значениях среднемесячных и особенно среднегодовых температур воздуха, повышенной влажности воздуха; число дней с относительной влажностью более $80 \%$ в летние месяцы в среднем превышает 20. Своеобразны и другие климатические показатели: частые затяжные моросящие дожди; высокая скорость южных и юго-восточных ветров. Среднегодовое количество осадков составляет 684 мм (иногда превышают 1000 мм в год), из них в зимний период выпадает 108 мм, а в летний - 576 мм (84\% годового количества осадков). При прохождении тайфунов за один дождь может выпадать от 130 до 200 мм осадков. С повышенной влажностью воздуха связано дополнительное увлажнение почв до 50 мм в год за счет конденсации влаги на растениях [17]. Характерной чертой климата является повышенная туманность, достигающая в июне-июле 250-275 часов в месяц.

На островах Сидорова и Герасимова под высокосомкнутым широколиственным лесом с хорошо развитым травяным покровом создаются благоприятные условия для формирования преимущественно буроземов темных с характерным для этого типа набором генетических горизонтов: 
O-AU-AUBMBM-BMC. Высокая гумусированность характерна не только для темногумусового горизонта $\mathrm{AU}$ (содержание гумуса по Тюрину в нем составляет 14,9 \%), но и для нижележащего, переходного к иллювиальной части профиля горизонта AUBM (5,8 \%). На о. Герасимова на участках с разреженным травостоем (проективное покрытие не более 30 \%) наряду с буроземами темными распространены буроземы типичные с характерным для этого типа набором генетических горизонтов: O-AY-AYBMBM-BMC. Содержание гумуса в серогумусовом горизонте АY составляет 7,9 \%, а в переходном АҮВМ резко падает и не превышает 1,8 \%.

Рассматриваемые острова располагаются в подзоне хвойношироколиственных лесов, которые по островным территориям проникают южнее, чем на материке, произрастают в атипичных для материка условиях и характеризуются специфическими островными сочетаниями растений. Так, на о-ве Большой Пелис можно встретить шиповник морщинистый под пологом леса, в древостое которого отмечается повышенная роль вишни Максимовича, микромелиса ольхолистного, а в подлеске обилие барбариса амурского, крушины даурской, а также галофитов в составе травостоя $[18,19]$. В силу своего географического положения эти острова активно осваивались человеком. По мере их освоения некогда распространённые здесь хвойные, хвойно-широколиственные леса трансформировались в широколиственные, собственно дубовые и дубово-липовые леса (с примесью берёз, ясеней, клёнов), а последние - в изреженные остепнённые дубняки с мощным травянистым покровом, остепнённые злаково-разнотравно-кустарниковые и злаково-разнотравные группировки. Лесистость островных территорий существенно снизилась.

Рельеф и почвообразующие породы. Для большей части исследуемого района характерен низкогорный слаборасчленённый рельеф с абсолютными высотами около 200 м над уровнем моря. Крутизна горных склонов варьирует от $3^{\circ}-10^{\circ}$ до $15^{\circ}-20^{\circ}$. В ряде мест склоны гор переходят в слабонаклонные $\left(1^{\circ}-3^{\circ}\right)$ в сторону морского побережья террасовидные участки или плосковерхие увалы остатков скульптурных плиоценовых террас.

Исследуемую территорию слагают породы верхнепалеозойского интрузивного комплекса из кварцевых диоритов и гранодиоритов, а также гранитов. Диориты представляют светлые зеленовато-серые, а граниты светло-серые, реже розовато-серые или почти белые породы. 
Отличаются они небольшим (1-2\%) содержанием тёмноцветных минералов и преобладанием калиевого полевого шпата над плагиоклазом [20]. Почвообразующие породы островов довольно разнообразны. На о-вах Стенина и Большой Пелис они представлены преимущественно делювием гранитов, на о-ве Матвеева - делювием андезитодацита, на о-ве Гильденбрандта делювием лавобрекчии андезитов. Остров Де-Ливрона выделяется грубообломочным делювием из прослоев песчаников и алевролитов. На о-ве Дурново, в отличие от вышеперечисленных островов архипелага РимскогоКорсакова, почвы формируются на делювии карбонатно-кремнистых пород.

На о. Бычий под кустарниково-травяной растительностью формируются буроземы темные иллювиально-гумусовые с профилем O-AU-AUBMhiBMhi-BMC. Им свойственно наличие выраженных морфологических признаков иллювиирования гумуса в горизонтах AUBMhi и BMhi. Структурные отдельности этих горизонтов покрыты органо-минеральными кутанами серого и темно-серого цвета.

Содержание гумуса в буроземах темных иллювиально-гумусовых вниз по профилю убывает постепенно: в горизонте $\mathrm{AU}$ оно составляет 14 \%, в переходном AUBM - 7,5 \%, в иллювиально-гумусовом горизонте BMhi за счет иллювиирования в нем гумуса - 3,5 \%. Развитие иллювиально-гумусового процесса в буроземах о. Бычий связано с активным геохимическим воздействием моря, обусловливающим высокую подвижность гумуса.

В целом почвенный профиль буроземов на рассматриваемых островах, в отличие от буроземов островов центральной части залива Петра Великого, имеет ряд специфических черт. Лесная подстилка островов Сидорова и Герасимова характеризуется большой мощностью (6-9 см, в отдельных местах 15 см). Формированию мощных подстилок способствуют, с одной стороны, сплошная облесенность этих островов и высокая сомкнутость крон древесного полога на всей площади, включая береговые обрывы, а также хорошо развитый травяной покров. С другой стороны, местоположение островов в защищенной от сильных ветров бухте Табунная создает благоприятные условия для накопления опада, практически без выноса его с территории островов.

Кроме того, характерной чертой подстилки островов Сидорова и Герасимова является четкое ее деление на две части: верхнюю (до глубины 3-4 см), представленную сухими, рыхло лежащими неразложившимися прошлогодними листьями буровато-желтого цвета, и нижнюю - из влаж- 
ных средне и хорошо разложившихся растительных остатков темнокоричневого цвета, пронизанных мицелием грибов белого цвета. На о. Бычий, где древесный ярус отсутствует, подстилка маломощная и не превышает 2 см. Аккумулятивно-гумусовый горизонт буроземов на рассматриваемых островах темно-серого цвета (до черного). Он густо переплетен корнями трав, а на границе с подстилкой пронизан гифами грибов, что свидетельствует об их высокой микробиологической активности, характерной для буроземов юга Приморья. Иллювиальные горизонты буроземов на островах укороченные, щебнистокаменистые. В целом почвенный профиль имеет малую мощность - элюво-делювиальные отложения часто вскрываются на глубинах 30-45 см.

На большей части обезлесенных склонов мелкосопочника материкового побережья, занятых кустарниково-травяной растительностью, развиты буроземы типичные с маломощным и сильноскелетным профилем, чему способствовало, по-видимому, развитие эрозионных процессов в связи с антропогенным уничтожением лесной растительности. И только в небольших по площади залесенных ложбинах развиты буроземы темные. На таких участках наблюдается активное возобновление ясеня, березы, бархата.

На морской террасе под луговым разнотравьем формируются аллювиальные серо-гумусовые (дерновые) почвы с профилем, включающим горизонты: О-АY-АYС-С. По характеру скелетности он резко подразделяется на три части: верхнюю (горизонт АY) - с включением остроугольных обломков горных пород, среднюю (горизонт АYС) - с включением обломков горных пород и гальки, нижнюю (горизонт С) - в виде галечных отложений.

Содержание и профильная дифференциация гумуса являются очень важными диагностическими показателями почв. В бурозёмах Приморья содержание гумуса может варьировать от 4-6 до 16-17 и более - до 27\% [8, 9]. Островные бурозёмы характеризуются как очень высокогумусированные. Содержание гумуса в их аккумулятивно-гумусовых горизонтах изменяется от 10,46\% до 13,80\% в одних (бурозёмы о-вов Стенина, Де-Ливрона, Матвеева) и от 17,05 до 26,0\% - в других (бурозёмы о-вов. Де-Ливрон, Дурново и Гильденбрандта). Одной из причин столь существенных различий в гумусированности этих групп бурозёмов являются их различия по содержанию обменных катионов: в первых содержание обменных катионов составляет 1720 мг-экв, а во вторых - 50-75 мг-экв. По мере увеличения в почвах, почвенных растворах щелочноземельных элементов активизируется гумусооб- 
разование и гумусонакопление, что и обуславливает отмеченные различия в гумусированности исследуемых бурозёмов.

Отличительными и характерными чертами островных бурозёмов являются повышенная подвижность гумуса в пределах профиля и как следствие этого - повышенная гумусированность горизонтов. Даже на глубине одного метра в горизонте ВМС содержание гумуса характеризуется довольно высокими значениями и изменяется от 1,20 до 2,70\%. Это подтверждает наше предположение $[10,11,12]$, что в приокеанических условиях складывается благоприятная обстановка для формирования бурозёмов с глубокой пропиткой почвенного профиля гумусом и более высоким содержанием гумуса в подгумусовых горизонтах, чем в континентальных бурозёмах.

В типичных бурозёмах, где аккумулятивно-гумусовый горизонт сменяется переходным горизонтом АYBM, содержание гумуса в последнем варьирует в большинстве разрезов от 2,80 до 3,90\% и в остальных разрезах - от 6,3 до 6,60\%. По мере дальнейшего увеличения содержания гумуса в этой части профиля островных бурозёмов до 7,0-8,1-9.3\% горизонт АYВМ эволюционирует в иллювиально-гумусовый горизонт ВMhi, имеющий серую, тёмно-серую окраску.

Гумификация в островных бурозёмах идет по фульватно-гуматному типу, что подтверждается данными группового и фракционного состава гумуса. Работы С.В. Зонна $[2,13,14]$ и наши исследования $[11,15]$ показали, что фульватно-гуматный тип гумификации характерен для бурозёмов прибрежно-островной зоны юга Дальнего Востока, формирующихся в условиях морского гидротермически-импульверизационного режима. Этот режим обуславливает импульверизационный привнос морских вод, а также их компонентов в составе осадков, что и обуславливает своеобразие не только выветривания, но и гумусообразования.

Рассмотрим физико-химические свойства островных бурозёмов.

Данные физико-химических анализов рассматриваемых буроземов (табл. 1,2) свидетельствуют о том, что их формирование протекает в условиях значительного варьирования щелочно-кислотного состояния среды и имеет тенденцию к снижению кислотности в ряду: бурозем типичный - бурозем темный - бурозем темный иллювиально-гумусовый от сильнокислой, кислой до слабокислой и близкой к нейтральной реакции среды. Это обусловлено усилением геохимического воздействия моря на процессы почвообразования в рассматриваемом ряду буроземов, которому соответ- 
ствует следующий сукцессионный ряд растительности: малотравяные широколиственные леса - изреженные дубовые леса с хорошо развитым травяным покровом - травяно-кустарниковые группировки. Для буроземов типичных характерна сильнокислая реакция среды - величина $\mathrm{pH}$ солевой вытяжки аккумулятивно-гумусовыхых горизонтов варьирует в пределах $3,74-4,40$.

Буроземы темные имеют преимущественно средне- и слабокислую реакцию среды - величина $\mathrm{pH}$ солевой имеет тенденцию к повышению по сравнению с таковой у буроземов типичных (4,38-4,63-5,50).

Для буроземов темных иллювиально-гумусовых характерна явно выраженная слабокислая и близкая к нейтральной реакция среды - $\mathrm{pH}$ солевой 5,25-5,82.

Обменная кислотность в островных буроземах обусловлена преимущественно обменным алюминием и, в меньшей степени, обменным водородом. Содержание обменного алюминия по Соколову в рассматриваемом ряду буроземов значительно снижается в аккумулятивно-гумусовых горизонтах буроземов типичных оно составляет 0,90-1,43 мг-экв / 100 г почвы, в буроземах темных значительно меньше - 0,12-0,16, а в буроземах темных иллювиальногумусовых не превышает 0,03-0,12 мг-экв / 100 г почвы.

Таблица 1

\section{Физико-химические свойства бурозёма}

типичного О-в Большой Пелис

\begin{tabular}{|c|c|c|c|c|c|c|c|}
\hline $\begin{array}{c}\text { Го- } \\
\text { ри } \\
\text { зонт }\end{array}$ & $\begin{array}{l}\text { Глуби } \\
\text { на, см }\end{array}$ & \multicolumn{2}{|c|}{$\begin{array}{c}\text { Гумус по Тюрину, } \\
\%\end{array}$} & $\mathrm{pH} \mathrm{H} \mathrm{H}_{2} \mathrm{O}$ & $\mathrm{pH} \mathrm{KCl}$ & \multicolumn{2}{|c|}{$\begin{array}{c}\text { Гидролитическая } \\
\text { кислотность, } \\
\text { мГ экв/ } 100 \text { г п }\end{array}$} \\
\hline $\begin{array}{c}\text { AY } \\
\text { BM } \\
\text { BM } \\
\text { C }\end{array}$ & $\begin{array}{r}4.5-14 \\
14-40 \\
40-63\end{array}$ & \multicolumn{2}{|c|}{$\begin{array}{l}9.15 \\
1.80 \\
0.80\end{array}$} & $\begin{array}{l}4.79 \\
4.80 \\
5.84\end{array}$ & $\begin{array}{l}3.74 \\
3.94 \\
4.24\end{array}$ & \multicolumn{2}{|c|}{$\begin{array}{c}15.58 \\
6.48 \\
4.20\end{array}$} \\
\hline $\begin{array}{c}\text { Го- } \\
\text { ри } \\
\text { зонт }\end{array}$ & $\begin{array}{l}\text { Глуби- } \\
\text { на, см }\end{array}$ & $\begin{array}{c}\text { Обмен- } \\
\text { ные ка- } \\
\text { тионы по } \\
\text { Соколо- } \\
\text { ву } \\
\text { Al }^{+3}\end{array}$ & $\begin{array}{c}\text { Обмен- } \\
\text { ные ка- } \\
\text { тионы по } \\
\text { Соколо- } \\
\text { ву } \\
\mathbf{H}^{+}\end{array}$ & $\begin{array}{c}\text { Обмен- } \\
\text { ные ка- } \\
\text { тионы по } \\
\text { Гедрой- } \\
\text { цу } \mathbf{H}^{+}\end{array}$ & $\begin{array}{c}\text { Обмен- } \\
\text { ные } \\
\text { катионы } \\
\text { по } \\
\text { Гедрой- } \\
\text { цу Са }{ }^{++}\end{array}$ & $\begin{array}{c}\text { Обмен- } \\
\text { ные } \\
\text { катионы } \\
\text { по } \\
\text { Гедрой- } \\
\text { цу } \\
\text { Mg }^{++}\end{array}$ & $\begin{array}{c}\text { Сте- } \\
\text { пень } \\
\text { насы- } \\
\text { щен } \\
\text { ности } \\
\text { основа } \\
\text { ниями, } \\
\%\end{array}$ \\
\hline
\end{tabular}




\begin{tabular}{|c|c|c|c|c|c|c|c|}
\hline AY & $4.5-14$ & 1,43 & 0,11 & 19,9 & 5,15 & 7,61 & 45 \\
BM & $14-40$ & 1,04 & 0,02 & 13,3 & 2,82 & 1,28 & 38 \\
BM & $40-63$ & 0,55 & 0,01 & 11,6 & 1,54 & 5,58 & 63 \\
C & & & & & \\
\hline
\end{tabular}

Таблийа 2

\section{Физико-химические свойства бурозёма типичного О-в Русский}

\begin{tabular}{|c|c|c|c|c|c|c|c|}
\hline $\begin{array}{c}\text { Гори- } \\
\text { зонт }\end{array}$ & $\begin{array}{c}\text { Глу- } \\
\text { бина, } \\
\text { см }\end{array}$ & \multicolumn{2}{|c|}{$\begin{array}{c}\text { Гумус по Тюри- } \\
\text { ну, \% }\end{array}$} & $\mathrm{pH} \mathrm{H}_{2} \mathrm{O}$ & $\mathrm{pH} \mathrm{KCl}$ & \multicolumn{2}{|c|}{$\begin{array}{l}\text { Гидролитическая } \\
\text { кислотность, } \\
\text { мг экв/ } 100 \text { г п }\end{array}$} \\
\hline AY & $4-19$ & \multicolumn{2}{|c|}{8,26} & 5,50 & 4,40 & \multicolumn{2}{|c|}{22,10} \\
\hline BM & $19-34$ & \multicolumn{2}{|c|}{2,41} & 5,60 & 4,60 & \multicolumn{2}{|c|}{22,14} \\
\hline $\mathrm{BM}$ & $34-46$ & \multicolumn{2}{|c|}{2,07} & 5,70 & 4,30 & \multicolumn{2}{|c|}{11,00} \\
\hline $\begin{array}{c}\text { Гори- } \\
\text { зонт }\end{array}$ & $\begin{array}{c}\text { Глу- } \\
\text { бина, } \\
\text { см }\end{array}$ & $\begin{array}{c}\text { Обмен- } \\
\text { ные ка- } \\
\text { тионы } \\
\text { по Со- } \\
\text { колову } \\
\mathbf{A l}^{+3}\end{array}$ & $\begin{array}{c}\text { Обмен- } \\
\text { ные ка- } \\
\text { тионы } \\
\text { по Со- } \\
\text { колову } \\
\mathbf{H}^{+}\end{array}$ & $\begin{array}{c}\text { Обмен- } \\
\text { ные ка- } \\
\text { тионы } \\
\text { по } \\
\text { Гедрой } \\
\text { цу } \mathbf{H}^{+}\end{array}$ & $\begin{array}{c}\text { Обмен- } \\
\text { ные } \\
\text { катио- } \\
\text { ны по } \\
\text { Гедрой } \\
\text { цу Са } \\
++\end{array}$ & $\begin{array}{c}\text { Обмен- } \\
\text { ные } \\
\text { катио- } \\
\text { ны по } \\
\text { Гедрой } \\
\text { цу } \\
\mathbf{M g}^{++}\end{array}$ & $\begin{array}{c}\text { Степень } \\
\text { насыщен- } \\
\text { ности ос- } \\
\text { нова } \\
\text { ниями, \% }\end{array}$ \\
\hline AY & 4-19 & 0,90 & $0,($ & & 28,90 & 19,90 & 6 \\
\hline BM & $19-34$ & 4,20 & 0,0 & - & 7,90 & 1,90 & 3 \\
\hline $\mathrm{BM}$ & $34-46$ & 3,30 & 0,07 & & 8,90 & 3,90 & 54 \\
\hline
\end{tabular}

Таблица 3

Физико-химические свойства бурозёма тёмного О-в Русский

\begin{tabular}{|c|c|c|c|c|c|c|c|}
\hline $\begin{array}{l}\text { Гори- } \\
\text { зонт }\end{array}$ & $\begin{array}{c}\text { Глуби- } \\
\text { на, см }\end{array}$ & \multicolumn{2}{|c|}{$\begin{array}{c}\text { Гумус } \\
\text { по Тюрину, \% }\end{array}$} & $\mathrm{pH} \mathrm{H} \mathrm{H}_{2} \mathrm{O}$ & $\mathrm{pH} \mathrm{KCl}$ & \multicolumn{2}{|c|}{$\begin{array}{c}\text { Гидролитическая } \\
\text { кислотность, } \\
\text { мГ экв/ } 100 \text { г } \\
\text { почвы }\end{array}$} \\
\hline $\mathrm{AU}$ & $2.5-13$ & \multicolumn{2}{|c|}{14.05} & 6.40 & 5.50 & \multicolumn{2}{|c|}{11.87} \\
\hline AUBM & $13-38$ & \multicolumn{2}{|c|}{3.41} & 5.30 & 4.30 & \multicolumn{2}{|c|}{10.81} \\
\hline BMC & $38-58$ & \multicolumn{2}{|c|}{1.38} & 5.50 & 4.20 & \multicolumn{2}{|c|}{6.27} \\
\hline $\begin{array}{c}\text { Гори- } \\
\text { зонт }\end{array}$ & $\begin{array}{c}\text { Глуби- } \\
\text { на, см }\end{array}$ & $\begin{array}{c}\text { Обмен- } \\
\text { ные ка- } \\
\text { тионы } \\
\text { по Со- } \\
\text { колову } \\
\mathbf{A l}^{+3}\end{array}$ & $\begin{array}{c}\text { Обмен- } \\
\text { ные ка- } \\
\text { тионы } \\
\text { по Со- } \\
\text { колову } \\
\mathbf{H}^{+}\end{array}$ & $\begin{array}{c}\text { Обмен- } \\
\text { ные ка- } \\
\text { тионы } \\
\text { по } \\
\text { Гедрой- } \\
\text { цу } \mathbf{H}^{+}\end{array}$ & $\begin{array}{c}\text { Обмен- } \\
\text { ные } \\
\text { катионы } \\
\text { по } \\
\text { Гедрой- } \\
\text { цу Са }{ }^{++}\end{array}$ & $\begin{array}{c}\text { Обмен- } \\
\text { ные } \\
\text { катионы } \\
\text { по } \\
\text { Гедрой- } \\
\text { цу } \\
\mathbf{M g}^{++}\end{array}$ & $\begin{array}{c}\text { Сте- } \\
\text { пень } \\
\text { насы- } \\
\text { щен } \\
\text { ности } \\
\text { основа } \\
\text { ниями, } \\
\%\end{array}$ \\
\hline
\end{tabular}




\begin{tabular}{|c|c|c|c|c|c|c|c|}
\hline AU & $2.5-13$ & 0.14 & 0.14 & 6.20 & 29.67 & 10.78 & 77 \\
AUBM & $13-38$ & 0.94 & 0.06 & 4.08 & 2.59 & 5.69 & 43 \\
BMC & $38-58$ & 0.74 & 0.03 & 3.23 & 2.03 & 5.06 & 53 \\
\hline
\end{tabular}

Таблииа 4

Физико-химические свойства бурозёма тёмного О-в Стенина

\begin{tabular}{|c|c|c|c|c|c|}
\hline Горизонт & $\begin{array}{c}\text { Глубина, } \\
\text { см }\end{array}$ & $\begin{array}{c}\text { Гумус } \\
\text { по Тюрину, \% }\end{array}$ & $\mathrm{pH} \mathrm{H} \mathrm{H}_{2} \mathrm{O}$ & $\mathrm{pH} \mathrm{KCl}$ & $\begin{array}{c}\text { Гидролит. } \\
\text { кислотность, } \\
\text { мг экв/ } 100 \text { г п }\end{array}$ \\
\hline $\mathrm{AU}$ & $3-12$ & 12.10 & 5.26 & 4.38 & 7.40 \\
\hline AUBM & $12-27$ & 3.09 & 5.02 & 4.09 & 4.40 \\
\hline BM1 & $27-50$ & 2.54 & 5.22 & 4.19 & 3.10 \\
\hline BM2 & $50-90$ & 1.20 & 5.44 & 4.17 & 2.70 \\
\hline BMC & $90-100$ & 0.70 & 5.57 & 4.09 & 2.95 \\
\hline
\end{tabular}

\begin{tabular}{|c|c|c|c|c|c|c|c|}
\hline $\begin{array}{c}\text { Гори- } \\
\text { зонт }\end{array}$ & $\begin{array}{c}\text { Глуби- } \\
\text { на, см }\end{array}$ & $\begin{array}{c}\text { Обмен- } \\
\text { ные ка- } \\
\text { тионы } \\
\text { по Со- } \\
\text { колову } \\
\mathbf{A l}^{+3}\end{array}$ & $\begin{array}{c}\text { Обмен- } \\
\text { ные ка- } \\
\text { тионы } \\
\text { по Со- } \\
\text { колову } \\
\mathbf{H}^{+}\end{array}$ & $\begin{array}{c}\text { Обмен- } \\
\text { ные ка- } \\
\text { тионы } \\
\text { по } \\
\text { Гедрой- } \\
\text { цу } \mathbf{H}^{+}\end{array}$ & $\begin{array}{c}\text { Обмен- } \\
\text { ные } \\
\text { катионы } \\
\text { по } \\
\text { Гедрой- } \\
\text { цу Са }\end{array}$ & $\begin{array}{c}\text { Обмен- } \\
\text { ные } \\
\text { катионы } \\
\text { по } \\
\text { Гедрой- } \\
\text { цу } \\
\mathbf{M g}^{++}\end{array}$ & $\begin{array}{c}\text { Сте- } \\
\text { пень } \\
\text { насы- } \\
\text { щен } \\
\text { ности } \\
\text { основа } \\
\text { ниями, } \\
\%\end{array}$ \\
\hline $\mathrm{AU}$ & $3-12$ & 0.16 & 0.21 & 5.90 & 8.10 & 19.10 & 78 \\
\hline AUBM & $12-27$ & 0.07 & 0.21 & 4.80 & 4.80 & 4.90 & 68 \\
\hline BM1 & $27-50$ & 0.06 & 0.66 & 2.90 & 2.90 & 1.90 & 61 \\
\hline BM2 & $50-90$ & 0.06 & 0.57 & 1.40 & 1.40 & 2.40 & 59 \\
\hline $\mathrm{BMC}$ & $90-100$ & 0.06 & 0.58 & 1.70 & 1.70 & 1.40 & 51 \\
\hline
\end{tabular}

Таблийа 5

Физико-химические свойства бурозёма тёмного О-в Де-Ливрон

\begin{tabular}{|c|c|c|c|c|c|}
\hline $\begin{array}{c}\text { Гори- } \\
\text { зонт }\end{array}$ & $\begin{array}{c}\text { Глуби- } \\
\text { на, см }\end{array}$ & $\begin{array}{c}\text { Гумус } \\
\text { по Тюрину, \% }\end{array}$ & $\mathrm{pH} \mathrm{H}_{2} \mathrm{O}$ & $\mathrm{pH} \mathrm{KCl}$ & $\begin{array}{c}\text { Гидролит.кислотность, } \\
\text { мг экв/ 100 г почвы }\end{array}$ \\
\hline $\mathrm{AU}$ & $3-12$ & 11.57 & 5.20 & 4.63 & 6.10 \\
$\mathrm{AUBM}$ & $12-27$ & 2.80 & 4.86 & 3.90 & 5.40 \\
$\mathrm{BM} 1$ & $27-55$ & 1.56 & 5.20 & 3.95 & 3.30 \\
$\mathrm{BMC}$ & $55-100$ & 1.17 & 5.30 & 4.00 & 2.70 \\
$\mathrm{BMC}$ & $100-$ & 1.02 & 5.10 & 4.07 & 2.15 \\
& 110 & & & \\
\hline
\end{tabular}




\begin{tabular}{|c|c|c|c|c|c|c|c|}
\hline $\begin{array}{c}\text { Гори- } \\
\text { зонт }\end{array}$ & $\begin{array}{c}\text { Глуби- } \\
\text { на, см }\end{array}$ & $\begin{array}{c}\text { Обмен- } \\
\text { ные ка- } \\
\text { тионы } \\
\text { по Со- } \\
\text { колову } \\
\mathbf{A l}^{+3}\end{array}$ & $\begin{array}{c}\text { Обмен- } \\
\text { ные ка- } \\
\text { тионы } \\
\text { по Со- } \\
\text { колову } \\
\mathbf{H}^{+}\end{array}$ & $\begin{array}{c}\text { Обмен- } \\
\text { ные ка- } \\
\text { тионы } \\
\text { по } \\
\text { Гедрой- } \\
\text { цу } \mathbf{H}^{+}\end{array}$ & $\begin{array}{c}\text { Обмен- } \\
\text { ные } \\
\text { катионы } \\
\text { по } \\
\text { Гедрой- } \\
\text { цу Са }\end{array}$ & $\begin{array}{c}\text { Обмен- } \\
\text { ные } \\
\text { катионы } \\
\text { по } \\
\text { Гедрой- } \\
\text { цу } \\
\mathbf{M g}^{++}\end{array}$ & $\begin{array}{c}\text { Степень } \\
\text { насыщен- } \\
\text { ности осно- } \\
\text { ваниями, \% }\end{array}$ \\
\hline $\begin{array}{c}\text { AU } \\
\text { AUBM } \\
\text { BM1 } \\
\text { BMC } \\
\text { BMC }\end{array}$ & $\begin{array}{c}3-12 \\
12-27 \\
27-55 \\
55-100 \\
100- \\
110\end{array}$ & $\begin{array}{l}0.12 \\
0.06 \\
0.04 \\
0.04 \\
0.10\end{array}$ & $\begin{array}{l}0.22 \\
1.16 \\
1.04 \\
0.72 \\
0.46\end{array}$ & $\begin{array}{l}4.10 \\
1.20 \\
2.60 \\
6.20 \\
4.20\end{array}$ & $\begin{array}{c}12.40 \\
3.70 \\
2.50 \\
3.40 \\
4.90\end{array}$ & $\begin{array}{l}5.50 \\
3.60 \\
1.00 \\
1.90 \\
3.60\end{array}$ & $\begin{array}{l}72 \\
85 \\
57 \\
66 \\
79\end{array}$ \\
\hline
\end{tabular}

Таблица 6

Физико-химические свойства бурозёма тёмного иллювиально-гумусового о-в Большой Пелис

\begin{tabular}{|c|c|c|c|c|c|c|c|}
\hline $\begin{array}{c}\text { Гори- } \\
\text { зонт }\end{array}$ & $\begin{array}{c}\text { Глуби- } \\
\text { на, см }\end{array}$ & \multicolumn{2}{|c|}{$\begin{array}{c}\text { Гумус } \\
\text { по Тюрину, \% }\end{array}$} & $\mathrm{pH} \mathrm{H} \mathrm{H}_{2} \mathrm{O}$ & $\mathrm{pH} \mathrm{KCl}$ & \multicolumn{2}{|c|}{$\begin{array}{c}\text { Гидролит.кислотность, } \\
\text { мг экв/ } 100 \text { г почвы }\end{array}$} \\
\hline $\begin{array}{l}\text { AU } \\
\text { BMhi }\end{array}$ & $\begin{array}{l}4-19 \\
19-48\end{array}$ & \multicolumn{2}{|c|}{$\begin{array}{c}25.4 \\
8.0\end{array}$} & $\begin{array}{l}5.82 \\
5.78\end{array}$ & $\begin{array}{l}5.34 \\
4.71\end{array}$ & \multicolumn{2}{|c|}{$\begin{array}{l}12.95 \\
12.08\end{array}$} \\
\hline $\begin{array}{c}\text { Гори- } \\
\text { зонт }\end{array}$ & $\begin{array}{l}\text { Глуби- } \\
\text { на, см }\end{array}$ & $\begin{array}{c}\text { Обмен- } \\
\text { ные ка- } \\
\text { тионы } \\
\text { по Со- } \\
\text { колову } \\
\mathbf{A l}^{+3}\end{array}$ & $\begin{array}{c}\text { Обмен- } \\
\text { ные ка- } \\
\text { тионы } \\
\text { по Со- } \\
\text { колову } \\
\mathbf{H}^{+}\end{array}$ & $\begin{array}{c}\text { Обмен- } \\
\text { ные ка- } \\
\text { тионы } \\
\text { по } \\
\text { Гедрой- } \\
\text { цу } \mathbf{H}^{+}\end{array}$ & $\begin{array}{c}\text { Обмен- } \\
\text { ные } \\
\text { катионы } \\
\text { по } \\
\text { Гедрой- } \\
\text { цу Са }\end{array}$ & $\begin{array}{c}\text { Обмен- } \\
\text { ные } \\
\text { катионы } \\
\text { по } \\
\text { Гедрой- } \\
\text { цу } \\
\mathbf{M g}^{++}\end{array}$ & $\begin{array}{c}\text { Степень } \\
\text { насыщен- } \\
\text { ности осно- } \\
\text { ваниями, \% }\end{array}$ \\
\hline $\begin{array}{c}\text { AU } \\
\text { BMhi }\end{array}$ & $\begin{array}{c}4-19 \\
19-48\end{array}$ & $\begin{array}{l}0.03 \\
0.07\end{array}$ & $\begin{array}{l}0.12 \\
0.05\end{array}$ & $\begin{array}{l}9.50 \\
12.8\end{array}$ & $\begin{array}{l}34.33 \\
14.67\end{array}$ & $\begin{array}{l}27.72 \\
12.22\end{array}$ & $\begin{array}{l}83 \\
67\end{array}$ \\
\hline
\end{tabular}




\section{Физико-химические свойства бурозёма тёмного}

иллювиально-гумусового о-в Русский

\begin{tabular}{|c|c|c|c|c|c|c|c|}
\hline $\begin{array}{c}\text { Гори- } \\
\text { зонт }\end{array}$ & $\begin{array}{l}\text { Глуби- } \\
\text { на, см }\end{array}$ & \multicolumn{2}{|c|}{$\begin{array}{c}\text { Гумус } \\
\text { по Тюрину, \% }\end{array}$} & $\mathrm{pH} \mathrm{H} \mathrm{H}_{2} \mathrm{O}$ & $\mathrm{pH} \mathrm{KCl}$ & \multicolumn{2}{|c|}{$\begin{array}{c}\text { Гидролит.кислотность, } \\
\text { мг экв/ } 100 \text { г почвы }\end{array}$} \\
\hline $\begin{array}{c}\text { AU } \\
\text { AUBM } \\
\text { hi } \\
\text { BMhi }\end{array}$ & $\begin{array}{c}5-16 \\
16-25 \\
25-53\end{array}$ & \multicolumn{2}{|c|}{$\begin{array}{c}14.92 \\
6.23 \\
4.08\end{array}$} & $\begin{array}{l}6.00 \\
5.60 \\
5.50\end{array}$ & $\begin{array}{l}5.40 \\
4.60 \\
4.30\end{array}$ & \multicolumn{2}{|c|}{$\begin{array}{c}7.61 \\
11.65 \\
7.17\end{array}$} \\
\hline $\begin{array}{c}\text { Гори- } \\
\text { зонт }\end{array}$ & $\begin{array}{c}\text { Глуби- } \\
\text { на, см }\end{array}$ & $\begin{array}{c}\text { Обмен- } \\
\text { ные ка- } \\
\text { тионы } \\
\text { по Со- } \\
\text { колову } \\
\mathbf{A l}^{+3}\end{array}$ & $\begin{array}{c}\text { Обмен- } \\
\text { ные ка- } \\
\text { тионы } \\
\text { по Со- } \\
\text { колову } \\
\mathbf{H}^{+}\end{array}$ & $\begin{array}{c}\text { Обмен- } \\
\text { ные ка- } \\
\text { тионы } \\
\text { по } \\
\text { Гедрой- } \\
\text { цу } \mathbf{H}^{+}\end{array}$ & $\begin{array}{c}\text { Обмен- } \\
\text { ные } \\
\text { катионы } \\
\text { по } \\
\text { Гедрой- } \\
\text { цу Са }\end{array}$ & $\begin{array}{c}\text { Обмен- } \\
\text { ные } \\
\text { катионы } \\
\text { по } \\
\text { Гедрой- } \\
\text { цу } \\
\mathbf{M g}^{++}\end{array}$ & $\begin{array}{c}\text { Степень } \\
\text { насыщен- } \\
\text { ности осно- } \\
\text { ваниями, \% }\end{array}$ \\
\hline $\begin{array}{c}\text { AU } \\
\text { AUBM } \\
\text { hi } \\
\text { BMhi }\end{array}$ & $\begin{array}{l}5-16 \\
16-25 \\
25-53\end{array}$ & $\begin{array}{l}0.12 \\
0.18 \\
0.42\end{array}$ & $\begin{array}{l}0.14 \\
0.06 \\
0.04\end{array}$ & $\begin{array}{l}1.87 \\
3.26 \\
3.88\end{array}$ & $\begin{array}{c}20.40 \\
14.02 \\
4.83\end{array}$ & $\begin{array}{c}15.62 \\
4.11 \\
2.88\end{array}$ & $\begin{array}{l}83 \\
61 \\
52\end{array}$ \\
\hline
\end{tabular}

Таблийа 8

Физико-химические свойства бурозёма тёмного

иллювиально-гумусового о-в Де-Ливрон

\begin{tabular}{|c|c|c|c|c|c|c|c|}
\hline $\begin{array}{l}\text { Гори- } \\
\text { зонт }\end{array}$ & $\begin{array}{l}\text { Глуби- } \\
\text { на, см }\end{array}$ & \multicolumn{2}{|c|}{$\begin{array}{c}\text { Гумус } \\
\text { по Тюрину, \% }\end{array}$} & $\mathrm{pH} \mathrm{H} \mathrm{H}_{2} \mathrm{O}$ & $\mathrm{pH} \mathrm{KCl}$ & \multicolumn{2}{|c|}{$\begin{array}{c}\text { Гидролит.кислотность, } \\
\text { мг экв/ } 100 \text { г почвы }\end{array}$} \\
\hline $\begin{array}{c}\text { AU } \\
\text { AUBM } \\
\text { BMhi } \\
\text { BMC } \\
\text { BMC }\end{array}$ & $\begin{array}{c}3-8 \\
8-14 \\
14-50 \\
50-85 \\
85-100\end{array}$ & \multicolumn{2}{|c|}{$\begin{array}{c}17.05 \\
6.60 \\
3.60 \\
1.70 \\
1.30\end{array}$} & $\begin{array}{l}5.85 \\
5.04 \\
4.93 \\
5.24 \\
4.99\end{array}$ & $\begin{array}{l}5.25 \\
4.18 \\
4.07 \\
3.66 \\
3.72\end{array}$ & \multicolumn{2}{|c|}{$\begin{array}{l}4.60 \\
6.80 \\
7.35 \\
5.78 \\
4.80\end{array}$} \\
\hline $\begin{array}{c}\text { Гори- } \\
\text { зонт }\end{array}$ & $\begin{array}{l}\text { Глуби- } \\
\text { на, см }\end{array}$ & $\begin{array}{c}\text { Обмен- } \\
\text { ные ка- } \\
\text { тионы } \\
\text { по Со- } \\
\text { колову } \\
\mathbf{A l}^{+3}\end{array}$ & $\begin{array}{c}\text { Обмен- } \\
\text { ные ка- } \\
\text { тионы } \\
\text { по Со- } \\
\text { колову } \\
\mathbf{H}^{+}\end{array}$ & $\begin{array}{c}\text { Обмен- } \\
\text { ные ка- } \\
\text { тионы } \\
\text { по } \\
\text { Гедрой- } \\
\text { цу } \mathbf{H}^{+}\end{array}$ & $\begin{array}{c}\text { Обмен- } \\
\text { ные } \\
\text { катионы } \\
\text { по } \\
\text { Гедрой- } \\
\text { цу Са }{ }^{++}\end{array}$ & $\begin{array}{c}\text { Обмен- } \\
\text { ные } \\
\text { катионы } \\
\text { по } \\
\text { Гедрой- } \\
\text { цу } \\
\mathbf{M g}^{++}\end{array}$ & $\begin{array}{c}\text { Степень } \\
\text { насыщен- } \\
\text { ности осно- } \\
\text { ваниями, \% }\end{array}$ \\
\hline
\end{tabular}




\begin{tabular}{|c|c|c|c|c|c|c|c|}
\hline AU & $3-8$ & 0.10 & 0.20 & 1.00 & 43.60 & 2.40 & 91 \\
AUBM & $8-14$ & 0.06 & 0.60 & 7.40 & 13.70 & 4.90 & 73 \\
BMhi & $14-50$ & 0.06 & 2.78 & 1.60 & 3.90 & 1.90 & 44 \\
BMC & $50-85$ & 0.06 & 2.94 & 6.40 & 6.40 & 4.90 & 63 \\
BMC & $85-100$ & 0.05 & 2.17 & 4.40 & 11.90 & 13.30 & 84 \\
\hline
\end{tabular}

Таблиия 9

\section{Физико-химические свойства бурозёма тёмного}

иллювиально-гумусового о-в Дурново

\begin{tabular}{|c|c|c|c|c|c|}
\hline Горизонт & $\begin{array}{c}\text { Глубина, } \\
\text { см }\end{array}$ & $\begin{array}{c}\text { Гумус по } \\
\text { Тюрину, \% }\end{array}$ & $\mathrm{pH} \mathrm{\textrm {H } _ { 2 } \mathrm { O }}$ & $\mathrm{pH} \mathrm{KCl}$ & $\begin{array}{c}\text { Гидролит.кислотность, } \\
\text { мГ экв/ 100 г почвы }\end{array}$ \\
\hline $\mathrm{AU}$ & $5-21$ & 19.42 & 6.63 & 5.82 & 2.40 \\
$\mathrm{BM} 1 \mathrm{hi}$ & $21-39$ & 9.34 & 6.33 & 5.45 & 3.20 \\
$\mathrm{BM} 2$ & $39-60$ & 2.53 & 5.61 & 4.74 & 2.70 \\
$\mathrm{BMC}$ & $60-82$ & 2.75 & 5.82 & 4.60 & 1.60 \\
$\mathrm{BMC}$ & $82-110$ & 0.91 & 6.08 & 4.54 & 1.30 \\
\hline
\end{tabular}

\begin{tabular}{|c|c|c|c|c|c|c|c|}
\hline $\begin{array}{c}\text { Гори- } \\
\text { зонт }\end{array}$ & $\begin{array}{c}\text { Глуби- } \\
\text { на, см }\end{array}$ & $\begin{array}{c}\text { Обмен- } \\
\text { ные ка- } \\
\text { тионы } \\
\text { по Со- } \\
\text { колову } \\
\mathbf{A l}^{+3}\end{array}$ & $\begin{array}{c}\text { Обмен- } \\
\text { ные ка- } \\
\text { тионы } \\
\text { по Со- } \\
\text { колову } \\
\mathbf{H}^{+}\end{array}$ & $\begin{array}{c}\text { Обмен- } \\
\text { ные ка- } \\
\text { тионы } \\
\text { по } \\
\text { Гедрой- } \\
\text { цу } \mathbf{H}^{+}\end{array}$ & $\begin{array}{c}\text { Обмен- } \\
\text { ные } \\
\text { катионы } \\
\text { по } \\
\text { Гедрой- } \\
\text { цу Са } \mathbf{C a}^{++}\end{array}$ & $\begin{array}{c}\text { Обмен- } \\
\text { ные } \\
\text { катионы } \\
\text { по } \\
\text { Гедрой- } \\
\text { цу } \\
\mathbf{M g}^{++}\end{array}$ & $\begin{array}{c}\text { Степень } \\
\text { насыщен- } \\
\text { ности осно- } \\
\text { ваниями, \% }\end{array}$ \\
\hline $\mathrm{AU}$ & $5-21$ & 0.08 & 0.07 & 0.80 & 58.60 & 16.00 & 97 \\
\hline BM1hi & $21-39$ & 0.10 & 0.06 & 1.20 & 28.60 & 9.80 & 92 \\
\hline BM2 & $39-60$ & 0.04 & 0.04 & 1.40 & 11.90 & 5.90 & 87 \\
\hline $\mathrm{BMC}$ & $60-82$ & 0.04 & 0.08 & 0.40 & 13.90 & 7.80 & 93 \\
\hline $\mathrm{BMC}$ & $82-110$ & 0.05 & 0.08 & 0.40 & 16.40 & 9.10 & 95 \\
\hline
\end{tabular}

Данные наших исследований свидетельствуют о специфичности гумусообразования и гумусонакопления в исследуемом ряду островных бурозёмов. Островные бурозёмы залива Петра Великого формируются в своеобразных биоклиматических условиях. Установлено, что в условиях прогрессирующей антропогенной трансформации широколиственных лесов прослеживается сопряженное нарастание геохимического воздействия моря на формирование бурозёмов. Это определяет своеобразие морфоло- 
гического строения, физико-химических свойств и процессов гумусообразования и гумусонакопления.

\section{Литература}

1. Таргульян. В.О. Проблема почвенной специфики островных экосистем // Экология и рациональное использование островных экосистем. Владивосток. ДВНЦ АН СССР, 1978. С. 8-9.

2. Зонн. С.В. Особенности аллитного выветривания и почвообразования на островах Приморья и дальнего Востока // Изучение и освоение природной среды. М: Наука, 1976. С125-137.

3. Иванов А. Н. Проблемы изучения ландшафтов островов // Изв. РГО. - 2009. - Вып. 4. - С. 4-11.

4. Колесников Б. П. Очерк растительности Дальнего Востока. - Хабаровск: Хабар. кн. изд-во, 1955. - 104 с

5. Классификация и диагностика почв России / Сост. Л. Л. Шишов, В. Д. Тонконогов, И. И. Лебедева, М. И. Герасимова. - Смоленск: Ойкумена, 2004. - 342 с.

6. Гаврилюк Ф. Я. Полевые исследования и картирование почв. Ростов н/Д: Изд-во Рост. ун-та, 1990. —224 с.

7. Пыльцевой анализ. - М.: Гос. изд-во геол. лит., 1950. - 571 с

8. Крейда Н.А. Почвы хвойно-широколиственных и широколиственных лесов Приморского края // Уч. зап. Дальневост. ун-та, 1970. Т. 27, ч. $2.229 \mathrm{c}$.

9. Иванов Г.И. Почвообразование на юге Дальнего Востока. М. : Наука, 1976. 200 с.

10. Пшеничников Б.Ф. Континентально-приокеанические бурозёмы, их развитие и эволюция (на примере япономорского побережья). Автореферат диссер. на соискание уч. степ. д.б.н. - Владивосток: Издво Дальневост. ун-та, 1998. 39 с.

11.. Пшеничников Б.Ф., Пшеничникова Н.Ф. Генезис и эволюция приокеанических бурозёмов (на примере япономорского побережья). Владивосток: Изд-во Дальневост. ун-та, 2002. 202 с.

12. Пшеничников Б.Ф., Пшеничникова Н.Ф. Почвы островов и побережья // Дальневосточный морской биосферный заповедник. Исследования. / отв. ред. А.Н. Тюрин. - Владивосток: Дальнаука, 2004. Т. 1. С. 251-283. 
13. Зонн С.В. О почвообразовании, генетических особенностях и освоении почв КНДР // Генезис и география почв зарубежных стран по исследованиям советских географов. - М. : Наука, 1978. С. 58-82.

14. Зонн С.В. Современные проблемы генезиса и географии почв. М. :Наука, 1983. 168 с.

15. Пшеничников Б.Ф., Пшеничникова Н.Ф., Латышева, Л.А. Влияние процессов гумусообразования и гумусонакопления на морфогенетическое своеобразие бурозёмов прибрежной части южного Сихотэ-Алиня // Лесные экосистемы Северо-Восточной Азии и их динамика: материалы междунар. конф., Владивосток, 22-26 авг. 2006 г. - Владивосток : Дальнаука, 2006. - С. 72-78.

16. Ластовецкий Е.И., Якунин Л.П. Гидрометеорологическая характеристика ДВГМЗ // Цветковые растения островов ДВМБЗ. - Владивосток : ДВНЦ АН СССР, 1981. С. 18-33.

17. Прилуцкий А.Н. Структура водного баланса в дубняках Южного Приморья // Гидроклиматические исследования в лесах Советского Дальнего Востока. - Владивосток, 1973. С. 125-129.

18. Пробатова Н.С., Селедец В.П, Соколовская А.П. Галофильные растения морских побережий советского Дальнего Востока: числа хромосом и экология // Комаровские чтения. Вып. 31. - Владивосток: ДВНЦ АН СССР, 1984. С. 89-116.

19. Селедец В.П. Растительность острова Большой Пелис // Цветковые растения островов ДВМБЗ. - Владивосток: ДВНЦ АН СССР, 1981. С.115-129.

20. Геология СССР. Т. XXXII, Приморский край: ч. І. Геологическое описание. - М. : Недра, 1969. 696 с. 